\title{
Level Of Political Engagement In UK
}

${ }^{1}$ S M Nazmuz Sakib (Orchid- https://orcid.org/0000-0001-9310-3014) (sakibpedia@gmail.com)

${ }^{1}$ Graduate of BSc in Business Studies

School of Business And Trade

Pilatusstrasse 6003, 6003 Luzern, Switzerland
${ }^{1}$ Student of LLB(Hon's)

Department of Law

Dhaka International University

House \# 4, Road \# 1, Block - F, Dhaka 1213

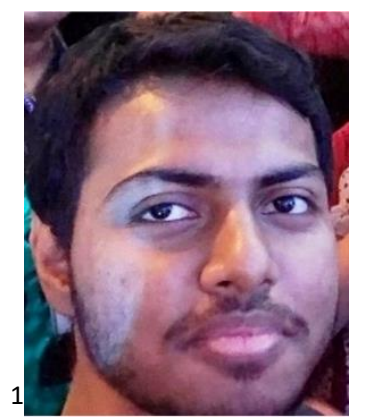

${ }^{1}$ Author Biography

S M Nazmuz Sakib is an eLearning expert and done more than 500 MOOCs or Massive Open Online Courses and experienced as an instructor in sites like Udemy. He has completed his BSc in Business Studies from School of Business And Trade, Switzerland with CGPA 4 in the scale of 4 and $97.06 \%$ grade marks on an average. He is also a certified Google IT Support Professional, Google Data Analytics Professional and IBM Customer Engagement Specialist Professional. 


\section{Abstract}

If citizens do not recognize, respect, or partake in the democratic process, they are regarded as politically disengaged. In the United Kingdom, political retrenchment takes distinct forms and is more common among some populations than among others. This paper addresses the features of various political disengagement measures: selected policy perceptions; degree of participation in political activities; registration for elections; voting; and elected leaders, candidates and Members of Parliament. Youths, in particular, are less likely to register as voters, vote and get elected, and engage in some political events, whereas elderly people have more negative perceptions toward politics. Councilors, candidates as well as Members of Parliament have an average age of over 50 years. Moreover, it was less likely to register people from minority ethnic groups to vote, have them voted into political positions, and convince them to vote. White people are more likely to be politically negative and to take very little part in political action.

Keywords: Political, Politics, UK Politics, Political Engagement, Politics in UK

\section{Introduction}

In Western democracies, decreased voter turnout and confidence in government bodies has raised questions regarding political disengagement. Despite recent boosts, voting attendance in the UK has not returned to the 1950s. According to recent reports, confidence in the government has also fallen. In the first place, the share of those who trusted in the government dropped from 38\% in 1986 to 17\% in 2013 (Flinders 2015). Politicians' confidence has fluctuated by around $9 \%$. But vote and confidence are not the only indications of political participation. The 
degree of political involvement in the UK seem far higher, when gauged by other variables. Citizens elect a government to administer their common affairs in democratic societies. People may affect government decisions through voting for specific candidates or parties, as well as by other means such as lobbying, protesting, and petitioning (Flinders 2015). Democratic or political engagement, involvement, or participation are words used to describe such events.

The word "political participation" will be used in this paper to describe a number of activities. Academics such as David Sanders et al. defines political engagement as: A person (group) can be perceived democratically [politically] engaged in the system of government if he/she (it) is actively involved with the democratic system and related constitutional principles on a behavioral and psychological basis. Positive participation does not imply approval; it may take the form of reform-oriented (nonviolent) dissent and protest (Harris et al. 2018). On the contrary, groups and individuals are disengaged politically if they are not involved in a positive way with the political system (in terms of attitudes and behavior). This term refers to a lack of involvement as well as discontentment or disappointment with politics, as well as disconnection, isolation, and apathy. Persons disengaged or unable to vote are disenfranchised because of nationality restrictions, for example. To ensure that their actions and policies reflect the interests of their constituents, representative governments are thought to require reasonably high levels of democratic participation (Bennet and Kippin 2018). As a consequence, low levels of political participation are thought to have an effect on a government's legitimacy, policies, and the broader political structure.

\section{Literature Review}

Political disengagement, molded by various factors, can take a variety of forms. Political scientist Paul Webb contends that in Britain there are two kinds of political groups: Dissatisfied 
democrats: informed, more socially active people who have lofty aspirations of what democracy can accomplish and who do not want more opportunities to engage and do not like current politics.;

Stealth democrats are people who are less educated, have a lower economic status and are less passionate about politics unless it is absolutely appropriate (Parvin 2015). These people used political parties to voice their concerns, but as party politics have changed, they no longer identify with these (usually left-wing) parties.

Jennings and Stoker who are renowned scholars in this field also distinguish between different kinds of political disengagement based on the various convictions, such as that political leaders cannot make a significant difference; do not tell the whole truth about tough choices; or serve rich and powerful interests (Manning and Holmes 2013). They concluded that people of all types believe politicians and their actions, instead of the political system, are the issue. There are discrepancies about how to understand the fact that political participation varies between social groups. Some reject political unwillingness to fulfill their democratic obligations as a failure of individual citizens (Manning and Holmes 2013). Many researchers, on the other hand, point out how social conditions in society can discourage certain people from completely and fairly engaging in democratic system: people of all backgrounds may not have the same chances or resources to engage in political initiatives.

Regardless of the motive of different levels of involvement, political decisions can be more influenced by groups that take part more. As clarified in a 2014 study by the Institute for Public Policy Research (IPPR), such disproportionate impact raises concerns: Political inequalities occur if, despite constitutional equality of the democratic process, some individuals 
or groups are more influential in political decision-making and benefit from unfair results (Flinders 2015). As a result, it undermines a central democratic ideal, namely that all residents should be given equal recognition and equal opportunities to influence shared political decisionmaking irrespective of their status. There is also a threat of unequal participation, which generates a vicious circle in which people cannot participate, as they are disenfranchised from the political system, to disregard their interests and further withdrawal of prominent voices.

Political disengagement is a concept linked to a wide range of approaches and conduct, including political interest, involvement in and ability to participate in formal and informal initiatives. People can be detached in a number of ways, as previously mentioned. As a result, the emphasis of this paper is on a number of indicators, which are stated below (Apostolova et al. 2017). The study identifies traits that are linked to decreased levels of political engagement: people who have these traits are more likely to be politically detached. Nevertheless, there are significant variations among individuals who express these attributes, and people may have more than one of them: an individual may be young, female, and from an ethnic minority group. The data presented below does not always explain how and to what degree different aspects are linked to political disengagement. This isn't an all-inclusive list of traits that could be related to political disengagement (Fillieule 2010).

According to research, disengagement can be influenced by the perception of being different from the political majority, which can lead to feelings of alienation. There is, however, little research about how other factors affect various styles of disengagement.

a) Attitudes; Attitudes can determine political behavior: for instance, whether or not people believe they have a responsibility to vote is thought to be a significant predictor of 
whether or not they vote (Huddy and Bankert 2017). The percentage of people who feel they have a responsibility to vote has declined from 76 percent in 1987 to 66 percent in 2015, according to the British Social Attitudes survey.

b) Voter Registration; To vote, persons must be on the electoral database Certain individuals have a lower probability of being added to the register. The Electoral Commission checks the accuracy of electoral registers in the United Kingdom on a regular basis, estimating the proportion of registered voters on the records (Harrison 2020). Since the data they use makes it difficult to calculate the exact number of people who are qualified to vote in each area, their figures can only be used as a reference.

c) Voting; Voting is regarded as a primary predictor of political apathy. As seen above, voter participation in the United Kingdom has declined in recent decades and is still lower than it was in postwar polls prior to 1992. The EU Referendum in June 2016 had a higher turnout of 72.6 percent than any UK general election since 1992. Certain demographics are more inclined than others to participate. Voting characteristics data are not obtained, but social science research departments such as Ipsos Mori and NatGen have projections available (Harrison 2020). People are less likely to vote if they feel it is unlikely that the result of the elections will make a significant difference. This theory seems to be reinforced by the facts that participation is often higher in marginals, where single votes have a greater chance of affecting the outcome (although this gap has recently narrowed). People can also opt not to vote if they are happy with the country's current state (Harrison 2020). Major parties may aim their communications to individuals that are more interested in voting - and particularly for them - to create a vicious spiral in 
which participants react to (evident) political obliviousness to their aspirations by failing to vote.

d) Councilors, candidates and Members of parliament; The act of running for office is a direct demonstration of one's commitment to the democratic system. Furthermore, there is some proof that groups are more likely to be politically active if they see themselves (or people 'like them') represented in government agencies: research shows that women are more inclined to be politically active if they can end up voting for the candidates they support, especially if the candidate is a woman (Harrison 2020). A higher number of councillors, candidates, and MPs from a specific party can thus be interpreted as both a symbol and a catalyst of that group's political engagement. Local councillors are included in this measure because political participation in certain groups might be higher at the local level. In recent years there has been an increase in the number and proportion of women and ethnic minorities, with reduced numbers and proportions of women with manual labour.

Fears about turnout in the May 2021 elections have emerged as a result of the coronavirus pandemic. Concerns about safety could affect candidates, campaigns and participation. The British government is making some structural changes to the electoral processes of local elections in England, in consultation with the electoral community (James 2021). Actions shall include: Encourage people to seek postal votes early, provide additional funds for returning officers to cover supplementary costs for alternative polling stations, sanitation equipment and cleaning facilities, hiring extra staff, modifying lockdown regulations to make sure that voting or operating at the polls is an acceptable excuse to leave home, and limiting the number of voters required to sign nomination papers to minimize interaction between persons. 
How interested in politics:

How interested in politics

\begin{tabular}{|c|c|c|c|c|c|}
\hline & & Frequency & Percent & $\begin{array}{l}\text { Valid } \\
\text { Percent }\end{array}$ & $\begin{array}{c}\text { Cumulative } \\
\text { Percent }\end{array}$ \\
\hline \multirow{6}{*}{ Valid } & Very interested & 5415 & 12.2 & 12.2 & 12.2 \\
\hline & Quite interested & 15539 & 35.0 & 35.1 & 47.3 \\
\hline & Hardly interested & 15240 & 34.4 & 34.4 & 81.7 \\
\hline & $\begin{array}{l}\text { Not at all } \\
\text { interested }\end{array}$ & 8088 & 18.2 & 18.3 & 100.0 \\
\hline & Total & 44290 & 99.8 & 100.0 & \\
\hline & Refusal & 36 & .1 & & \\
\hline & Don't know & 57 & .1 & & \\
\hline Missing & & & & & \\
\hline & No answer & 4 & .0 & & \\
\hline & Total & 97 & .2 & & \\
\hline Total & & 44387 & 100.0 & & \\
\hline
\end{tabular}

The table below is a presentation on how the people are interested in politics. Those very interested are 5415 which is the smallest percentage compared to quite interested, hardly interested and not at all interested. This gives an indication that only about an eighth of the population can be highly associated with the interest in politics. 
Political system allows people to have a say in what government does

\begin{tabular}{|c|c|c|c|c|c|}
\hline & & Frequency & Percent & $\begin{array}{l}\text { Valid } \\
\text { Percent }\end{array}$ & $\begin{array}{c}\text { Cumulative } \\
\text { Percent }\end{array}$ \\
\hline & Not at all & 11158 & 25.1 & 25.7 & 25.7 \\
\hline & Very little & 16310 & 36.7 & 37.6 & 63.2 \\
\hline & Some & 12410 & 28.0 & 28.6 & 91.8 \\
\hline Valid & A lot & 3014 & 6.8 & 6.9 & 98.8 \\
\hline & $\begin{array}{l}\text { A great } \\
\text { deal }\end{array}$ & 537 & 1.2 & 1.2 & 100.0 \\
\hline & Total & 43429 & 97.8 & 100.0 & \\
\hline & Refusal & 87 & .2 & & \\
\hline & $\begin{array}{l}\text { Don't } \\
\text { know }\end{array}$ & 866 & 2.0 & & \\
\hline & No answer & 5 & .0 & & \\
\hline & Total & 958 & 2.2 & & \\
\hline Total & & 44387 & 100.0 & & \\
\hline
\end{tabular}

The above table indicates that few are allowed by the political system to have a say in what government does.63.2 percent are either having no say at all or very little. This shows how democracy is not exercised due to hindrance by the political system.

Regression analysis

The below table is represented by the function $\mathrm{Y}=1.147+0.243+0.102$

Dependent Variable: Political system allows people to have a say in what government does Independent variables: 1.Confidence in own ability to participate in politics

2. Trust in the legal system 
A unit change in political system allowing people to have a say in what government does will be influenced by a change of 0.243 in the confidence in own ability to participate in politics and 0.102 change in trust in the legal system.

Coefficients $^{\mathrm{a}}$

\begin{tabular}{|c|c|c|c|c|c|c|}
\hline \multirow{2}{*}{\multicolumn{2}{|c|}{ Model }} & \multicolumn{2}{|c|}{$\begin{array}{l}\text { Unstandardized } \\
\text { Coefficients }\end{array}$} & \multirow{2}{*}{$\begin{array}{l}\text { Standardized } \\
\text { Coefficients } \\
\text { Beta }\end{array}$} & \multirow[t]{2}{*}{$\mathrm{t}$} & \multirow[t]{2}{*}{ Sig. } \\
\hline & & B & Std. Error & & & \\
\hline \multirow{4}{*}{1} & (Constant) & 1.147 & .012 & & 95.518 & .000 \\
\hline & $\begin{array}{l}\text { Confident in own } \\
\text { ability to }\end{array}$ & & & & & \\
\hline & participate in politics & .243 & .004 & .270 & 60.216 & .000 \\
\hline & $\begin{array}{l}\text { Trust in the legal } \\
\text { system }\end{array}$ & .102 & .002 & .281 & 62.685 & .000 \\
\hline
\end{tabular}

Trust in the European Parliament

Trust in the European Parliament

\begin{tabular}{|c|c|c|c|c|}
\hline & Frequency & Percent & $\begin{array}{l}\text { Valid } \\
\text { Percent }\end{array}$ & $\begin{array}{c}\text { Cumulative } \\
\text { Percent }\end{array}$ \\
\hline No trust at all & 4887 & 11.0 & 11.9 & 11.9 \\
\hline 1 & 2237 & 5.0 & 5.5 & 17.4 \\
\hline 2 & 3469 & 7.8 & 8.5 & 25.9 \\
\hline 3 & 4352 & 9.8 & 10.6 & 36.5 \\
\hline 4 & 4599 & 10.4 & 11.2 & 47.8 \\
\hline 5 & 8065 & 18.2 & 19.7 & 67.5 \\
\hline
\end{tabular}




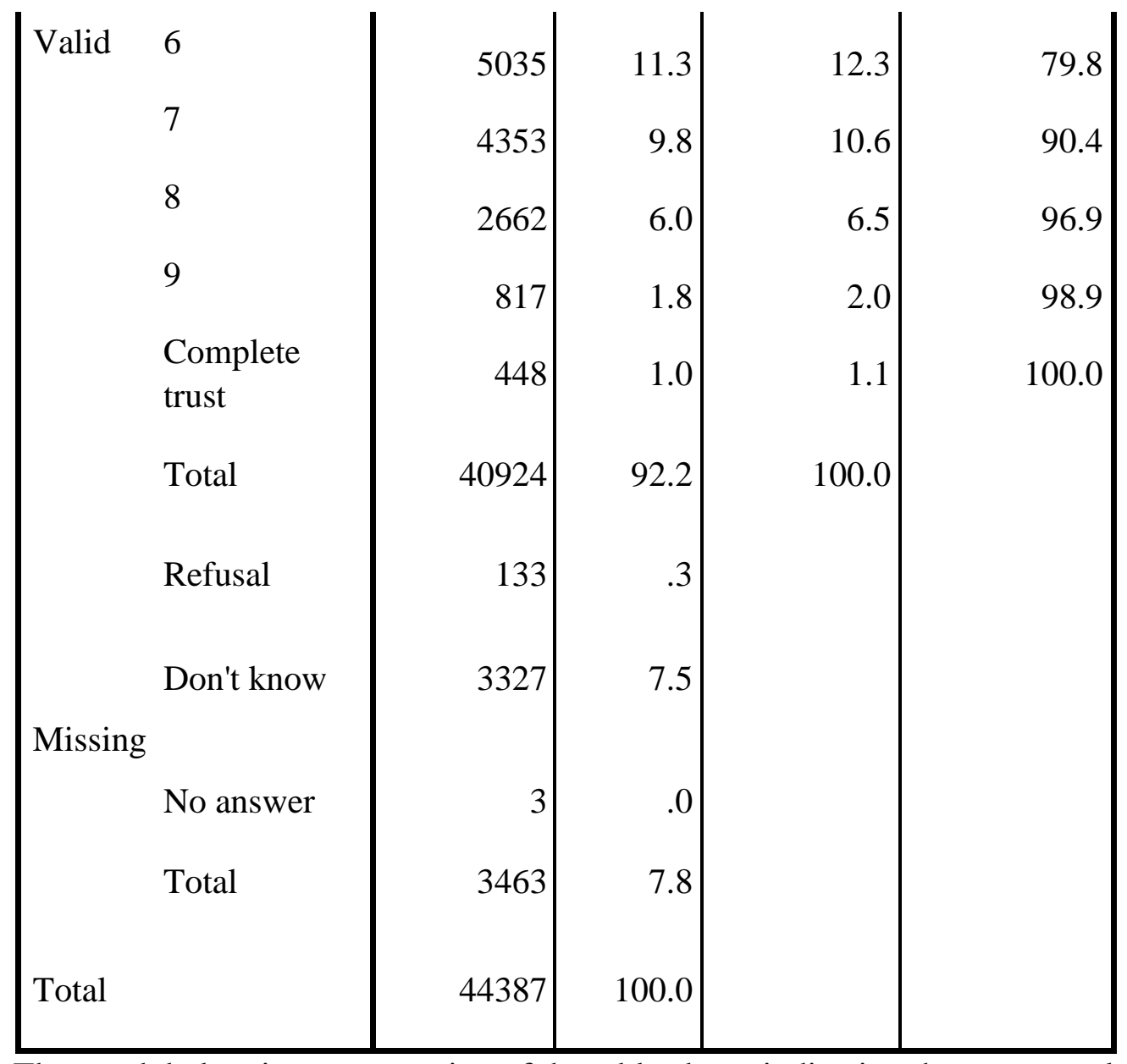

The graph below is representation of the table above indicating the trust people have in the Europeans parliament. The rating ranges from zero which is a no trust at all to 10 which is a complete trust in the European Parliament system. A 5 and 6 rating was highly given showing an average rating which is 29.5 percent of the total population. 


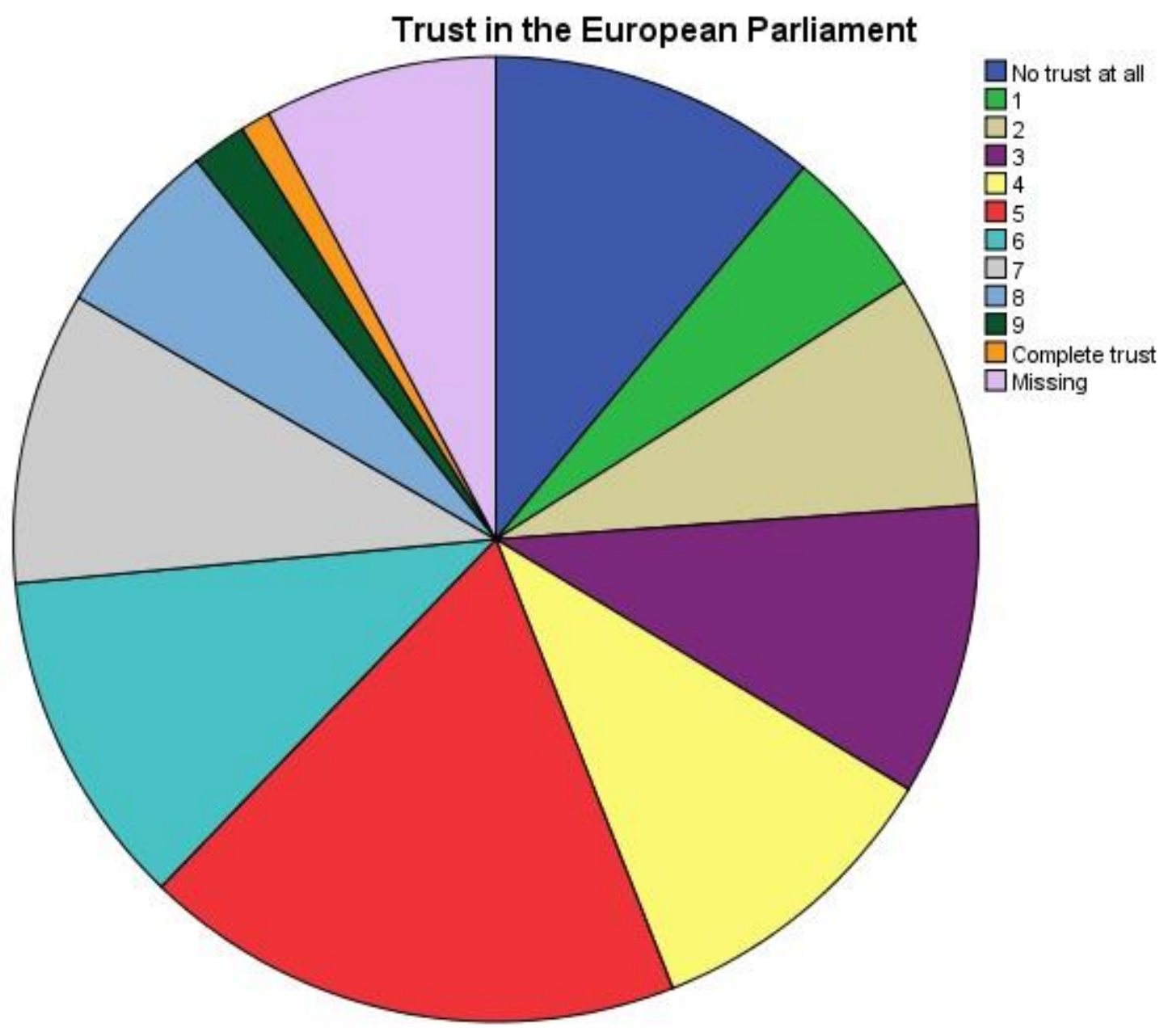




\section{Chi-Square Tests}

The Chi-Squire test was done to compare the association between the numbers that contacted the politicians or the government officials last 12 months and how they were interested in the politics. The result is significant since the value is less than the designated alpha level.

In this case, the P-value is smaller than the standard alpha value, so we reject the null hypothesis that asserts that the two variables are independent of each other. The data suggest that the number that contacted the politicians or government officials last 12 months is associated with the number interested in the politics.

\begin{tabular}{|c|c|c|c|}
\hline & Value & $\mathrm{df}$ & $\begin{array}{l}\text { Asymp. Sig. } \\
\text { (2sided) }\end{array}$ \\
\hline Pearson Chi-Square & $2314.613^{\mathrm{a}}$ & 3 & .000 \\
\hline Likelihood Ratio & 2205.616 & 3 & .000 \\
\hline $\begin{array}{l}\text { Linear-by-Linear } \\
\text { Association }\end{array}$ & 2133.493 & 1 & .000 \\
\hline $\mathrm{N}$ of Valid Cases & 44183 & & \\
\hline
\end{tabular}

a. 0 cells $(0.0 \%)$ have expected count less than 5 . The minimum

expected count is 827.91 .

\section{Discussion}

We don't seem to be in the middle of a crisis.. True, voter turnout has decreased, but this has been followed by a rise in non-electoral participation, which cannot be considered the cause 
of the drop in turnout. As a result, the British participation crisis is limited to the ballot box, and it is not indicative of a broader decrease in citizens' ability to engage with the political system. These differing trends are completely compatible with the rise in level of academic achievement in the last 20 years. Academic achievement has never had, and proceeds not having, a substantial effect on electoral participation, but its extension cannot be expected to shield turnout levels from other factors that may be leading to their decline. On the other hand, schooling has always been linked with anti-participation, which has grown by more than (moderate) in proportion to the increase in education achievement we would expect.

What signals are there from our research results about the possible variations in the level of political engagement in Britain in the next 20 years, especially when the proportion of educated adults keeps increasing? There is possibly no threat that the less well schooled will become more and more politically marginalized. They do not seem to give any indication that they have any less chances than they are already of being involved in politics outside the voting box. Nonetheless, election remains the only mode of political action in which participation levels amongst groups with varying educational backgrounds approach equality. There is, therefore, an increased risk that the opinions of those who are less knowledgeable will become silent if voting persists its dramatic fall and if non-electoral involvement increases.

\section{Conclusion}

Of course, it seems very probable that non-electoral turnout will increase, even when in part, this will depend on the absence of a decrease in personal accomplishment. And a better educated citizens seems more likely to engage in growing government efforts to consult the citizens in public policy development. Nevertheless, most types of political activity are, and are

likely to continue in the near future, preserved by a small minority. While Britain will evolve into 
a more democratic participation in the future, most people will continue to depend on their elected officials to make the best decisions for them for the foreseeable future.

\section{Reference List}

1. Apostolova, V., Uberoi, E. and Johnston, N., 2017. Political disengagement in the UK: who is disengaged?.

2. Bennett, N. and Kippin, S., 2014. The Green Party's Natalie Bennett on UKIP, political disengagement, and the European and local elections. Democratic Audit UK

3. Farthing, R., 2010. The politics of youthful antipolitics: representing the 'issue' of youth participation in politics. Journal of youth studies, 13(2), pp.181-195.

4. Fillieule, O., 2010. Some elements of an interactionist approach to political disengagement. Social movement studies, 9(1), pp.1-15.

5. Flinders, M., 2015. The general rejection? Political disengagement, disaffected democrats and

a. 'doing politics' differently. Parliamentary Affairs, 68(suppl_1), pp.241-254.

6. Flinders M. Not a Brexit Election? Pessimism, Promises and Populism 'UK-Style'. Parliamentary

a. Affairs. 2020 Sep 1;73(Supplement_1):225-42.

7. Huddy, L. and Bankert, A., 2017. Political partisanship as a social identity. In Oxford research encyclopedia of politics.

8. Harris, K.J., Gringart, E. and Drake, D., 2018. Leaving ideological groups behind: A model of disengagement. Behavioral sciences of terrorism and political aggression, 10(2), pp.91109.

9. Harrison, S., 2020. A vote of frustration? Young voters in the UK general election a. 2019. Parliamentary Affairs, 73(Supplement_1), pp.259-271.

10. James, T.S., 2021. New development: Running elections during a pandemic. Public Money \& 
a. Management, 41(1), pp.65-68.

11. Kelso, A., 2007. Parliament and political disengagement: Neither waving nor drowning. The

12. Political Quarterly, 78(3), pp.364-373.

13. Manning, N. and Holmes, M., 2013. 'He's snooty 'im': exploring 'white working class' political disengagement. Citizenship Studies, 17(3-4), pp.479-490.

14. Mitton, K., 2009. Engaging with Disengagement. Reintegrating Armed Groups After Conflict:

15. Politics, Violence and Transition, p.172.

16. Parvin, P., 2015. Is deliberative democracy feasible? Political disengagement and trust in liberal democratic states. The Monist, 98(4), pp.407-423.

17. Sloam, J., 2007. Rebooting democracy: Youth participation in politics in the UK. Parliamentary affairs, 60(4), pp.548-567. 